\title{
VIRAL DNA SEQUENCES IN PERIPHERAL BLOOD AND VERTICAL TRANSMISSION OF THE VIRUS: A DISCUSSION ABOUT BPV-1
}

\author{
Antonio Carlos de Freitas ${ }^{1,2 *}$; Claudemir de Carvalho ${ }^{1,2,4}$; Olga Brunner $^{1}$; Eduardo Harry Birgel-Junior ${ }^{3}$; \\ Alice Maria Melville Paiva Dellalibera ${ }^{3}$; Fernando José Benesi ${ }^{3}$; Lilian Gregory ${ }^{3}$; Willy Beçak ${ }^{1,2}$; \\ Rita de Cassia Stocco dos Santos ${ }^{1,2}$
}

${ }^{1}$ Laboratório de Genética, Instituto Butantan, São Paulo, SP, Brasil. ${ }^{2}$ Universidade de Taubaté, Taubaté, SP, Brasil. ${ }^{3}$ Clinica Médica, Faculdade de Medicina Veterinária e Zootecnia, Universidade de São Paulo, São Paulo, SP, Brasil.

${ }^{4}$ Faculdade de Pindamonhangaba, Pindamonhangaba, SP, Brasil.

This paper corresponds to an "extended abstract" selected for oral presentation in the $22^{\text {nd }}$ Brazilian Congress of Microbiology, held in Florianópolis, SC, Brazil, in November 17-20, 2003

\begin{abstract}
This study has detected BPV-1 DNA sequences in wart, blood and plasma samples collected from animals affected by papillomatosis, suggesting viral presence inside the cell. We sellected an animal in which we could detect BPV-1 DNA sequences in wart, blood, placenta and amniotic liquid samples and her offspring which presented BPV-1 DNA sequences in blood sample collected immediately after birth. These results show a possible vertical transmission of BPV-1.
\end{abstract}

Key words: BPV, viral vertical transmission, PCR detection.

\section{INTRODUCTION}

Papillomaviruses are a group of epitheliotropic and mucosotropic double-stranded DNA viruses affecting mammals, including man $(1,7)$. The cattle are affect by six different types of papillomaviruses (1). BPV-1/2 infection can cause skin warts, warts in teats, udder, penis and urinary bladder tumors $(1,2)$. Cancer develops as a result of interactions between the virus, chemical carcinogens and immunosuppressants that can be present for example in bracken fern $(1,3)$. Moura et al. discussed clastogenic action in animals raised in pastures with bracken fern, possibly infected by BPV (3). Leal et al. reported dramatic effects of the action of papillomavirus oncoproteins and quercetin on the chromatin of bovine cells (4). The presence of BPV DNA sequences in peripheral blood has been shown in clinically affected and healthy calves $(5,6,7)$. Stocco dos Santos et al. experimentally showed that peripheral blood samples of BPV2 infected cattle can through inoculation in health animals cause chromosome aberrations and urinary bladder lesions similar to those found in the naturally infected cattle (7).

HPV DNA sequence in the serum/plasma of women with cervical cancer (CC) has been reported (8). In cattle, there are few reports about the presence of the BPV in the peripheral blood and its possible effect causing papillomatosis. In this study, we discuss the BPV-1 presence in peripheral blood as well as a possible occurrence of vertical transmission.

\section{MATERIALS AND METHODS}

19 female animals (Bos taurus taurus X Bos taurus indicus, animals 1-19) were sellected due to the clinical manifestation of cutaneous papillomatosis and 01 offspring (animal 20) of animal $19.5 \mathrm{~mL}$ of blood were collected, kept at $4-8^{\circ} \mathrm{C}$. Plasma samples were obtained by centrifugation of blood samples (3300 rpm for $10 \mathrm{~min}$ ). The warts were removed by surgical method. Placenta, amniotic liquid and blood samples of the

*Corresponding author. Mailing address: Laboratório de Genética, Instituto Butantan. Av. Vital Brazil, 1500, Butantã. 05503-900, São Paulo, SP, Brasil. E-mail: acdefreitas@butantan.gov.br 
calf were collected. $25 \mathrm{mg}$ of tissue or $200 \mu \mathrm{L}$ of blood or amniotic liquid were used for DNA extraction in Qiagen columns according to respective protocol. 300ng of the extracted DNA were used for PCR analysis using specific primers for BPV-1:(Fw: 5' - GGA GCG CCT GCT AAC TAT AGG A - 3'; Rev: 5'-ATC TGT TGT TTG GGT GGT GAC-3'; $301 \mathrm{pb})$. $\beta$-globin gene was used to verify the quality of DNA for PCR procedures ( $\beta$-globin primers FW: 5 '-AAC CTC TTT GTT CAC AAC CAG - 3' and Rev: 5' - CAG ATG CTT AAC CCA CTG AGC - 3'; 450pb). PCR reactions were performed according to Stocco dos Santos et al. (7).

\section{RESULTS}

Table 1 shows the results of BPV-1 detection in wart, blood and plasma samples of bovines affected by cutaneous papillomatosis. The animals 7, 8, 10 and 11 were positive for BPV-1 in wart and blood samples and negative in the plasma

Table 1. BPV-1 detection in wart, blood and plasma samples of bovines affected by papillomatosis with control for DNA quality for PCR procedures through $\beta$-globin gene amplification in plasma sample.

\begin{tabular}{|c|c|c|c|c|}
\hline \multirow{2}{*}{ Animal } & \multicolumn{3}{|c|}{ BPV-1 detection } & \multirow{2}{*}{$\begin{array}{l}\text { Plasma } \\
\text {-Globin }\end{array}$} \\
\hline & Wart & Blood & Plasma & \\
\hline 1 & + & + & + & + \\
\hline 2 & + & + & + & + \\
\hline 3 & + & + & + & + \\
\hline 4 & + & + & + & + \\
\hline 5 & + & - & - & - \\
\hline 6 & + & + & ND & ND \\
\hline 7 & + & + & - & + \\
\hline 8 & + & + & - & + \\
\hline 9 & + & - & - & + \\
\hline 10 & + & + & - & + \\
\hline 11 & + & + & - & + \\
\hline 12 & + & + & + & + \\
\hline 13 & + & + & + & + \\
\hline 14 & + & + & ND & ND \\
\hline 15 & + & + & + & + \\
\hline 16 & + & + & ND & ND \\
\hline 17 & + & + & ND & ND \\
\hline 18 & + & + & ND & ND \\
\hline 19 & + & + & ND & ND \\
\hline \multirow[t]{2}{*}{20} & ND & + & ND & ND \\
\hline & $\begin{array}{c}20 / 20 \\
(100 \%)\end{array}$ & $\begin{array}{l}18 / 20 \\
(90 \%)\end{array}$ & $\begin{array}{c}7 / 13 \\
(49 \%)^{*}\end{array}$ & $\begin{array}{c}12 / 13 \\
(99 \%)^{*}\end{array}$ \\
\hline
\end{tabular}

ND: no determined

*: Plasma samples were obtained from 13/18 blood samples

$$
+ \text { : Presence } \quad-: \text { absence. }
$$

samples. However, the plasma samples were positive for $\beta$-globin amplification. These results suggest that BPV-1 DNA sequences are inside the bloodstream cells. BPV-1 detection in wart, blood, placenta and amniotic liquid results obtained from a bovine affected and her calf are presented in the Fig. 1. These results show evidences of vertical transmission of BPV-1. Confirmation of the PCR results was performed by Southern blot using BPV1 genome as probe or enzymatic digestion of PCR product with DdeI (results not showed).

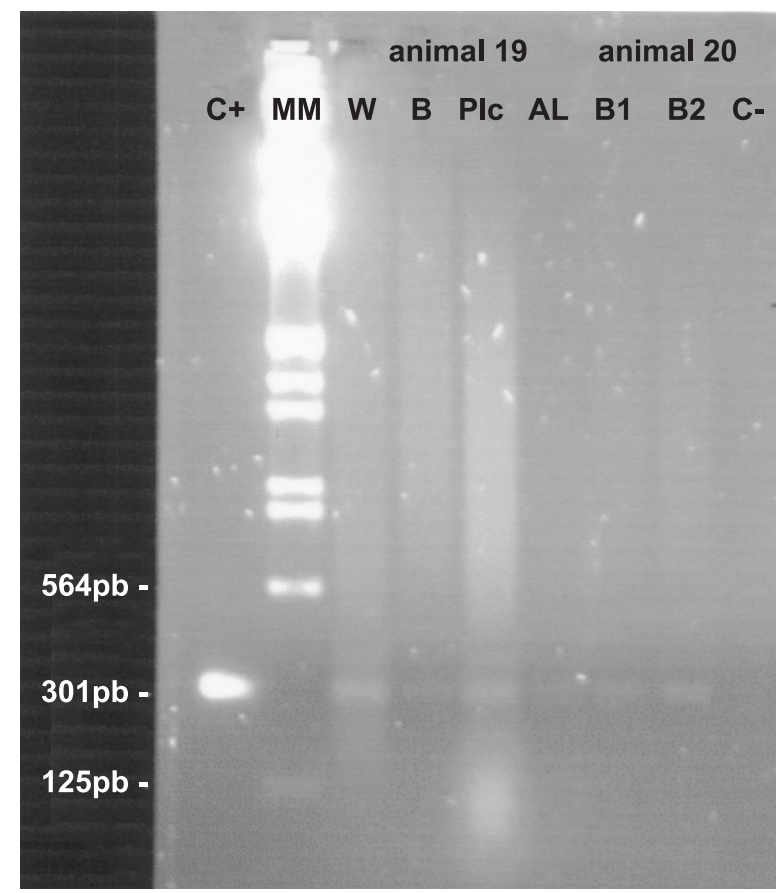

Figure 1. BPV-1 DNA detection by PCR in wart (W), blood (B), Placenta (Plc) and Amniotic liquid (AL) samples of bovine affected by papillomatosis (animal 19) and blood of her offspring collected immediately after birth (B1) and after ingestion of collostrum or milk (B2). Positive control of BPV-1 amplification. (MM) Molecular Marker, Lambda Hind III/HaeII.

\section{DISCUSSION}

This study reports the occurrence of BPV-1 DNA in wart and blood of affected animals with cutaneos papilomatosis suggesting the intracellular localization of BPV-1 DNA in bloodstream and showing the first evidence about vertical transmission of BPV-1. Evidence of papillomavirus in peripheral blood has been shown in cattle and human $(5,6,7,8)$ and the infectious action of these blood samples was suggested in calves (7). In this study $100 \%$ of the animals showed BPV-1 DNA in wart, 90\% showing BPV-1 DNA in blood. The results obtained from animals 7, 8, 10 and 11 indicate intracellular localization of 
the BPV-1 DNA in the bloodstream. Natural papilloma regression can be related to high concentration of lymphocytes in the lesion (9). The BPV genome eventually present in lymphocytes has been reported into clinically affected and healthy cattle $(5,6,7)$. Dramatic increase in chromosome aberration levels can be associated with BPV sequences, observed in experimentally and naturally infected animals, suggesting the possibility that BPV could act as eventual causal agent of chromosome fragility (7). In this study we report that offspring of one affected animal with BPV-1 detection in wart, blood, placenta, amniotic liquid samples, presented BPV-1 DNA sequences in blood samples collected immediately after birth (Fig. 1). The BPV2 transmission through infected blood samples was reported in bovines under controlled experimental conditions (7). The presence of BPV-1 DNA sequences into bloodstream cell indicates that the blood can be a transmission pathway for BPV-1 in order to reach new infection sites. This is the first report of natural vertical transmission of BPV-1 and show new evidence of the presence intracellular of DNA BPV-1 in bloodstream.

\section{ACKNOWLEDGMENTS}

FAPESP, CNPq, Fundação Butantan, UNITAU, FAPI.

\section{RESUMO}

\section{Presença de DNA viral no sangue periférico e transmissão vertical: uma discussão sobre BPV-1}

Neste estudo detectou-se DNA de BPV-1 em: verruga, sangue e plasma de animais afetados por papilomatose. Estes resultados trazem evidências sobre possível localização intracelular do
BPV-1 no sangue. Avaliamos um animal afetado por papilomatose e positivo para BPV-1 em amostras de verruga, sangue, placenta e líquido amniótico e que teve sua cria recém-nascida também positiva para BPV-1 no sangue. Estes resultados indicam possível transmissão vertical do BPV-1.

Palavras-chave: BPV, transmissão vertical, sangue periférico, PCR.

\section{REFERENCES}

1. Campo, M.S. Animal models of papillomavirus pathogenesis. Virus Res., 89:249-261, 2002.

2. Moura, J.W.; Stocco dos Santos, R.C.; Dagli, M.L.Z.; D'Angelino, J.L.; Birgel, E.H.; Beçak, W. Chromosome aberration in cattle raised on bracken fern pasture. Experientia, 44:785-788, 1988.

3. Leal, A.M.; Ferraz, O.P.; Carvalho, C.; Freitas, A.C.; Beniston, R.G.; Beçak, W.; Campo, M.S.; Stocco dos Santos, R.C. Quercetin induces structural chromosome aberrations and uncommon rearrangements in bovine cells transformed by the $\mathrm{E} 7$ protein of bovine papillomavirus type 4. Vet. Comp. Oncol., 1:15-21, 2003.

4. Freitas, A.C.; Pinto, A.P.A.T.R.; Carvalho, C.; Almeida, M.E.; Lindsey, C.J.; Kobashi, L.S.; Stoco dos Santos, R.C.; Beçak,W. Bovine Papillomavirus 1 and 4 in short term peripheral blood lymphocyte cultures of animals affected by papillomatosis. 19th International Papillomavirus Conference, 2001.

5. Campo, M.S. Latent papillomavirus infection in cattle. Res. Vet. Sci., 56:151-157, 1994.

6. Stocco dos Santos, R.C.; Lindsey, C.J.; Ferraz, O.P.; Pinto, J.R.; Mirandola, R.S.; Benesi, F.J.; Birgel, E.H.; Pereira, C.A.B.; Beçak, W. Bovine papillomavirus transmission and chromosomal aberrations: an experimental model. J. Gen. Virol., 79:2127-2135, 1998.

7. Mutirangura, A. Serum/plasma viral DNA. Ann. NY Acad. Sci., 945:5967, 2001.

8. Knowles, G.; O'Neil, B.W.; Campo, M.S. Phenotypical characterization of lymphocytes infiltrating regressing papillomas. J. Virol., 70:8451$8458,1996$. 